\title{
Mating System among Provenances of Sclerocarya birrea (A. Rich.) Hochst.
}

\author{
Violet J. Msukwa, ${ }^{1}$ Chimuleke R. Y. Munthali, ${ }^{1}$ Betserai I. Nyoka, ${ }^{2}$ Edward Missanjo $\mathbb{D}^{1},{ }^{3}$ \\ Alice Muchugi, ${ }^{4}$ Clement Okia, ${ }^{5}$ Simon Kang'ethe, ${ }^{4}$ and Herbert Jenya ${ }^{3}$ \\ ${ }^{1}$ Department of Forestry, Mzuzu University, Private Bag 201, Luwinga, Mzuzu 2, Malawi \\ ${ }^{2}$ World Agroforestry Centre, Chitedze Research Station, P.O. Box 30798, Lilongwe 3, Malawi \\ ${ }^{3}$ Department of Forestry, Forestry Research Institute of Malawi, P.O. Box 270, Zomba, Malawi \\ ${ }^{4}$ World Agroforestry Centre, ICRAF-Kenya, P.O. Box 30677, 00100 Gigiri, Nairobi, Kenya \\ ${ }^{5}$ World Agroforestry Centre, ICRAF-Uganda, P.O. Box 26416, Kampala, Uganda \\ Correspondence should be addressed to Edward Missanjo; edward.em2@gmail.com
}

Received 28 December 2018; Accepted 14 April 2019; Published 20 June 2019

Academic Editor: Ignacio García-González

Copyright (C) 2019 Violet J. Msukwa et al. This is an open access article distributed under the Creative Commons Attribution License, which permits unrestricted use, distribution, and reproduction in any medium, provided the original work is properly cited.

\begin{abstract}
Mating system of a species is critically important both genetically and ecologically in developing plans for breeding and gene conservation. This study was conducted to assess twenty provenances of Sclerocarya birrea (A. Rich.) Hochst. planted in Malawi. The trial was assessed for mating system and sex ratio at eighteen years of age. The results revealed that the mating system in $S$. birrea occurred from selfing, insect, and wind-mediated pollination. There were no significant $(P>0.05)$ differences on seed germination percentage among the three mating systems. The germination percentages were $47 \%, 44 \%$, and $43 \%$ for insect, wind, and self-pollinations, respectively. This implies that the seeds were viable in all the three mating systems. Production of viable seed from selfed flowers ruled out the possibility of apomixes in $S$. birrea. Most frequent flower visitors were the orders Hymenoptera and Lepidoptera with peak visitation period being from 7:00 to 11:30 hours in the morning and then 15:30 to 18:00 hours in the afternoon $(+2 \mathrm{GMT})$ when temperatures were cooler. There were significant $(P<0.05)$ variations in sex ratio among the provenances. Five provenances (Marracuene, Magamba, Tanzania pooled, Ngundu, and Matebeleland South) did not deviate significantly from sex ratio equality. The other provenances showed male-biased sex ratios.
\end{abstract}

\section{Introduction}

Mating system is the mode of gene transmission across generations that helps to determine the amount and distribution of genetic differences within and among populations of plant species $[1,2]$. It is a component of gene flow that combines selfing and outcrossing with pollination process as a key component in gene movement for seed production in flowering plants $[3,4]$. Understanding the mating system of a species is critically important both genetically and ecologically in developing plans for breeding and gene conservation [5].

The species of Sclerocarya birrea (A. Rich.) Hochst. is a member of the Anacardiaceae family [6,7]. It is a multipurpose fruit tree that is common and widespread throughout the Semiarid deciduous Savannas of much of Sub-Saharan Africa [8]. Although S. birrea is referred to as a dioecious species, careful examination of some trees of subsp. caffra in a number of studies in Southern Africa and Kenya has revealed isolated cases of monoecy [8-11]. For example, Teichman [12] reported an occurrence of 15 monoecious trees out of a sample of 119 and Todd [13] found 2 and 6 monoecious individuals in samples of 120 and 73 trees, respectively. Furthermore, reports in subspecies birrea in Kenya [14] indicated a few female flowers having some pollen-bearing anthers but self-pollination studies were not conducted to confirm whether these suspected hermaphrodites' flowers were self-compatible or not. In addition, Gouwakinnou et al. [15] also reported some individuals of male trees in an agroforestry system producing functionally hermaphroditic flowers with few fruits yet the flowers were different from those of female trees. The development of female flowers by male trees was previously documented in S. birrea subsp. 


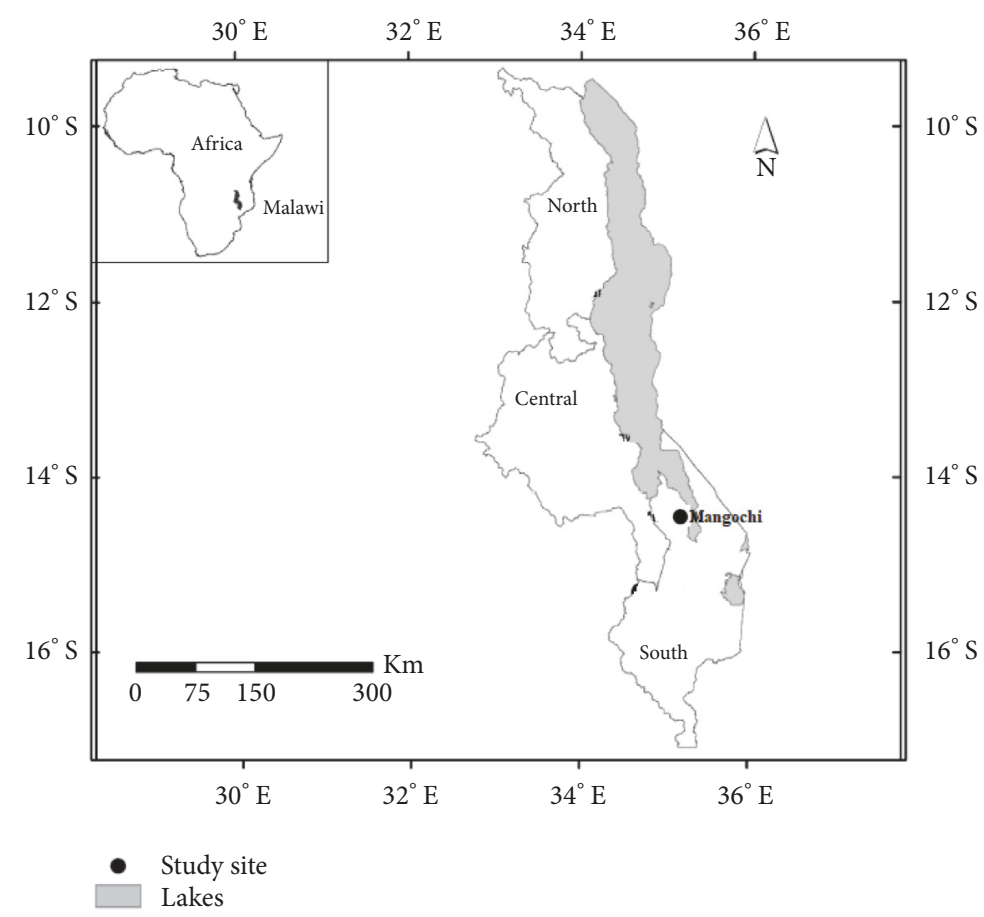

FIGURE 1: Map of Malawi showing the location of the study site.

caffra and were mistakenly included on the list of female plants yet they were hermaphroditic $[11,16]$. The presence of monoecy, occurrence of bisexual flowers in males, and sound pollen-bearing anthers in females of $S$. birrea $[12,14]$ suggest the possibility of self-pollination within the species. Consequently, Gouwakinnou et al. [15] recommended the need for further investigation on the breeding system of $S$. birrea specifically in the area of controlled pollination experiment combined with a parenthood analysis in order to ascertain the mating system of the species.

However, fruit production is the major attribute in fruit tree domestication and yet, in most dioecious species, fruit set is often limited by pollen availability, mostly due to the seclusion of male and female reproductive organs [17]. Thus, the reproductive success is dependent on the distribution and density of sexes within the range of pollinator agents [18]. Comparative surveys of dioecious flowering plants commonly reveal biased sex ratios, with male-biased ratios approximately twice as common as female-biased ratios [1921]. Under natural selection, a 1:1 sex ratio has been proven as theoretical and evolutionarily stable according to Fishers Central theory [22].

Since the establishment of $S$. birrea provenances trial in Malawi in 1999, a lot of published work has been conducted on the trial concentrating on tree survival [23], vegetative growth and fruit production [24-26], and morphometric fruit traits [27]. Despite these studies significant gaps in the issues of its mating system, sex ratio, phenology, and insect damage incidences still exist $[23,24,26]$.

In this paper we report on the mating systems and sex ratio of 19 provenances of Sclerocarya birrea subspp. caffra and one subspp. birrea growing in the provenances trial.
The information about mating system and sex ratio of a species is fundamental for successful domestication of the species. It provides the insight for possible crossing and enables the development of strategies for selection of superior genotypes for breeding and gene conservation for future use [28]. It is also important in assessing barriers to fruit set and seed viability [29]. Therefore, specifically, the present study was conducted to (1) determine mating system of $S$. birrea species; (2) determine viability of seed among different mating system; (3) determine if apomixes occur in S. birrea species; (4) identify frequent flower visitors and the time of visitation; and (5) determine the sex ratio under artificial planting.

\section{Materials and Methods}

2.1. Study Site. The provenance trial comprised of 22 provenances of S. birrea was established in February 1999 at Palm Forest Reserve in Mangochi $\left(14^{\circ} 28^{\prime} \mathrm{S}, 35^{\circ} 14^{\prime} \mathrm{E}\right.$ ) (Figure 1). The area is at an altitude of $469 \mathrm{~m}$ above sea level with mean annual rainfall of $800-1200 \mathrm{~mm}$ and mean annual temperature of $23.9^{\circ} \mathrm{C}$. The site has a high water table and sometimes is affected by seasonal flooding. The area is flat comprised of sandy soils that become loamy sand at over $50 \mathrm{~cm}$ depth. The acidity of the soil is of medium range but increases to about 7.1 in the subsoil. The dominating natural vegetation consists of palms (Hyphaene species) and Acacia's species [26]. It is situated about $290 \mathrm{~km}$ southeast of the capital Lilongwe.

2.2. Experimental Materials. Germplasm for trial was obtained through the World Agroforestry Centre (ICRAF) who 
TABLE 1: Characteristics of the mating system provenances.

\begin{tabular}{|c|c|c|c|c|c|c|}
\hline Provenance Name & Source Country & Number of Families & Latitude & Longitude & Altitude (m) & Number of Seedlings Used \\
\hline Chikhwawa & Malawi & 10 & $16^{\circ} 46^{\prime} S$ & $35^{\circ} 17^{\prime} \mathrm{E}$ & $100-300$ & 80 \\
\hline Mangochi & Malawi & 20 & $14^{\circ} 02^{\prime} \mathrm{S}$ & $34^{\circ} 53^{\prime} \mathrm{E}$ & $200-600$ & 80 \\
\hline Ntcheu & Malawi & 19 & $14^{\circ} 39^{\prime} \mathrm{S}$ & $34^{\circ} 46^{\prime} \mathrm{E}$ & $300-600$ & 80 \\
\hline Rumphi & Malawi & 20 & $10^{\circ} 59^{\prime} \mathrm{S}$ & $33^{\circ} 45^{\prime} \mathrm{E}$ & $900-1200$ & 80 \\
\hline Missira & Mali & 19 & $13^{\circ} 43^{\prime} \mathrm{N}$ & $8^{\circ} 27^{\prime} \mathrm{W}$ & 352 & 80 \\
\hline Magunde & Mozambique & 20 & $24^{\circ} 95^{\prime} \mathrm{S}$ & $32^{\circ} 92^{\prime} \mathrm{E}$ & $0-200$ & 80 \\
\hline Marracuene & Mozambique & 17 & $25^{\circ} 58^{\prime} \mathrm{S}$ & $32^{\circ} 95^{\prime} \mathrm{E}$ & $0-200$ & 80 \\
\hline Moamba & Mozambique & 20 & $25^{\circ} 55^{\prime} \mathrm{S}$ & $32^{\circ} 55^{\prime} \mathrm{E}$ & $0-200$ & 80 \\
\hline Kalimbeza & Namibia & 15 & $17^{\circ} 34^{\prime} \mathrm{S}$ & $24^{\circ} 34^{\prime} \mathrm{E}$ & 967 & 80 \\
\hline Ohangwena & Namibia & 20 & $17^{\circ} 30^{\prime} \mathrm{S}$ & $15^{\circ} 55^{\prime} \mathrm{E}$ & 1144 & 80 \\
\hline Oshikondilingo & Namibia & 16 & $17^{\circ} 35^{\prime} S$ & $15^{\circ} 45^{\prime} \mathrm{E}$ & 1030 & 80 \\
\hline Kalanga & Swaziland & 20 & $26^{\circ} 45^{\prime} \mathrm{S}$ & $31^{\circ} 45^{\prime} \mathrm{E}$ & 239 & 80 \\
\hline Magamba-Turiani & Tanzania & 9 & $5^{\circ} 40^{\prime} \mathrm{S}$ & $38^{\circ} 12^{\prime} \mathrm{E}$ & 530 & 80 \\
\hline Chalinze-Bangamoyo & Tanzania & 8 & $6^{\circ} 55^{\prime} \mathrm{S}$ & $38^{\circ} 20^{\prime} \mathrm{E}$ & 550 & $24^{*}$ \\
\hline Chigongwe-Dodoma & Tanzania & 9 & $6^{\circ} 04^{\prime} S$ & $35^{\circ} 45^{\prime} \mathrm{E}$ & 920 & $38^{*}$ \\
\hline Mandimu-Singida & Tanzania & 3 & $5^{\circ} 04^{\prime} \mathrm{S}$ & $35^{\circ} 08^{\prime} \mathrm{E}$ & 1460 & $6^{*}$ \\
\hline Mialo-Kondoa & Tanzania & 9 & $5^{\circ} 03^{\prime} \mathrm{S}$ & $36^{\circ} 21^{\prime} \mathrm{E}$ & 1150 & $36^{*}$ \\
\hline Mkata-Kilosa & Tanzania & 6 & $7^{\circ} 22^{\prime} \mathrm{S}$ & $37^{\circ} 50^{\prime} \mathrm{E}$ & 430 & $18^{*}$ \\
\hline Ubena-Bangamoyo & Tanzania & 9 & $6^{\circ} 11^{\prime} \mathrm{S}$ & $38^{\circ} 10^{\prime} \mathrm{E}$ & 305 & $38^{*}$ \\
\hline Choma & Zambia & 14 & $17^{\circ} 00^{\prime} \mathrm{S}$ & $27^{\circ} 00^{\prime} \mathrm{E}$ & 1300 & 80 \\
\hline Siavonga & Zambia & 16 & $16^{\circ} 30^{\prime} \mathrm{S}$ & $28^{\circ} 00^{\prime} \mathrm{E}$ & 520 & 80 \\
\hline Biriwiri & Zimbabwe & 15 & $19^{\circ} 50^{\prime} \mathrm{S}$ & $32^{\circ} 40^{\prime} \mathrm{E}$ & 1500 & 80 \\
\hline Matebeleland North & Zimbabwe & 14 & $18^{\circ} 00^{\prime} \mathrm{S}$ & $29^{\circ} 00^{\prime} \mathrm{E}$ & 996 & 80 \\
\hline Matebeleland South & Zimbabwe & 15 & $21^{\circ} 00^{\prime} \mathrm{S}$ & $32^{\circ} 45^{\prime} \mathrm{E}$ & 388 & 80 \\
\hline Mudzi & Zimbabwe & 15 & $16^{\circ} 17^{\prime} \mathrm{S}$ & $32^{\circ} 45^{\prime} \mathrm{E}$ & 400 & 80 \\
\hline Mzarabani & Zimbabwe & 15 & $19^{\circ} 50^{\prime} \mathrm{S}$ & $32^{\circ} 40^{\prime} \mathrm{E}$ & 600 & 80 \\
\hline Ngundu & Zimbabwe & 13 & $20^{\circ} 50^{\prime} \mathrm{S}$ & $32^{\circ} 50^{\prime} \mathrm{E}$ & 457 & 80 \\
\hline
\end{tabular}

Note: All the provenances had the same species (S. birrea ssp. caffra).

* Pooled provenance due to low seedling numbers during trial establishment

coordinated the range wide seed collection and provenance trial establishment. Germplasm of 30 provenances comprising 333 families from eight countries: Mozambique (3), Mali (1), Malawi (4), Namibia (3), Zambia (2), Zimbabwe (6), Swaziland (1), and Tanzania (10) were raised in the nursery at Forestry Research Nursery in Zomba, Malawi (Table 1). Most Tanzanian provenances had poor germination with Makadaga-Mbarali, Nyamahanga-Iringa, and KigwaTabora, all identified as subspecies multifoliolata not providing enough seedlings to be included in the field experiment. The other Tanzania provenances: Mkata-Morogoro, Ubena-Bagamoyo, Chalinze-Bagamoyo, Kigwe-Dodoma, Mialo-Kondoa, and Mandimu-Singida with relatively few seedlings were bulked. Only Magamba-Turiani from Tanzania had enough seedlings to be included as an individual treatment. Thus, there were 21 individual provenances and one bulked seed lot under observation (Table 1). Fruits were sown directly in black polythene tubes of standard size $15 \mathrm{~cm}$ X $10 \mathrm{~cm}$ laid flat and filled with soil collected from under a miombo woodland. Seed lots from Tanzania, Zambia, Malawi, Namibia, and Mali were sown in the nursery in February, 1998, whereas provenances from Mozambique, Zimbabwe, and Rumphi provenance from Malawi were sown in August, 1998.
2.3. Trial Design. The trial was laid out as a randomized complete block design (RCBD) with 333 families per block that were replicated four times. The treatments are represented by 22 provenances including one bulked with provenances from Tanzania. The bulked provenances from Tanzania and the Malian provenance, the only source from West Africa, was the only $S$. birrea ssp. birrea. Each treatment is a row plot of 20 trees that represent the total possible number of families collected for each provenance. The provenances were allocated randomly to the plots in each block. The families within provenance were also randomly allocated to maximize their representation in the trial. Where the provenance had less than 20 families, other families were repeated to have a full number of trees in a line plot and these were also assessed. The spacing is $4 \mathrm{~m}$ within row, i.e., between trees within a row and $5 \mathrm{~m}$ between rows.

\subsection{Data Collection}

2.4.1. Mating System. The mating system of S. birrea provenances was investigated according to Etcheverry et al. [30] methodology. Data was collected from 20 randomly selected female trees on which mating system experiment was set comprised of self-pollination, controlled wind pollination, 


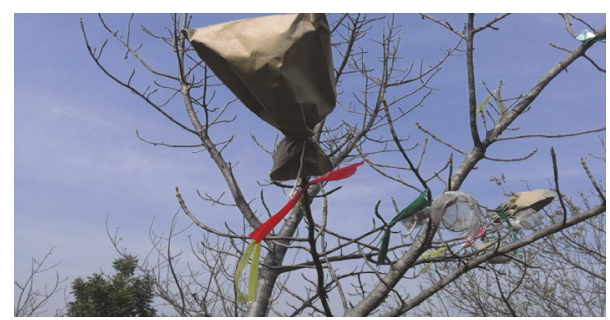

FIGURE 2: Mating system experiment showing three treatments randomized on the same tree.

and natural pollination (control). All the three treatments were applied on the same tree to minimize tree to tree variations (Figure 2). A total of 5 buds were used per treatment adding up to 15 buds per individual tree. Three treatments were tested as follows:

(i) Natural pollination (control): Five randomly selected buds per tree were left uncovered during the entire flowering period but the stalk holding the bud was tagged with a yellow ribbon for identity (Figure 2).

(ii) Controlled wind pollination: Five randomly selected buds per tree were bagged with fine net of $1.2 \mathrm{~mm}^{2}$ holes throughout the flowering period to prevent insect pollination but permit wind pollination.

(iii) Self-pollination (autogamy): Under this treatment five flower buds per tree were covered with khaki envelopes during the entire flowering period to prevent any foreign pollen or test the possibility of hermaphrodite flowers.

In treatments (ii) and (iii) the covering was removed after fruit set and the stalks were tagged with a distinctly colored labels for each treatment for identification (Figure 2). Fruit development was monitored fortnightly to fruit maturity.

2.4.2. Fruit Measurements. At fruit maturity all the fruits that developed under selfing, wind pollination, and open pollination were assessed. Whole fruit weight was measured in grams (g) using an electronic precision balance. The mass weight of the stone was measured in grams ( $g$ ) using an electronic precision balance after removing the rind and the pulp while fruit width and length were measured in centimeters $(\mathrm{cm})$ using a microcaliper.

2.4.3. Seed Test for Germination. Three seed lots from self, controlled wind pollination, and natural pollinations were initially sun dried for 21 days and then socked in water for 15 days. The water was replaced with fresh water after seven days. The seeds (stones) were removed from the water and sun dried for more than 21 days until cracks developed on the operculum. The operculum was removed before sowing in the polythene tubes. The removal of the operculum was used as a presowing treatment in order to break seed dormancy. After sowing, watering was done twice (morning and evening) per day until germination (or for 18 days).
2.4.4. Flower Visitors. Methodology used for collecting flower visitors was similar to Ngulube et al. [31]. The activity was done on $2^{\text {nd }}, 14^{\text {th }}$, and $21^{\text {st }}$ to $26^{\text {th }}$ September, 2017. Observation and collection of floral visitors using sweep nets were done from 07:30 hr to $12: 00 \mathrm{hr}$ and $15.00 \mathrm{~h}$ to 17.30 hr (+2 GMT). Insects were collected at random following the provenances/families that were in flower. The collected insects were preserved in alcohol for identification at Forestry Research Institute of Malawi (FRIM) laboratory.

2.4.5. Sex Ratio. These assessments were done during the flowering period of S. birrea from August to October, 2017. The sex of each flowering tree was assigned using male and female flowers. Sex ratios were determined for 20 provenances that were flowering except for the Rumphi one which was not flowering at the time of the study. All nonflowering trees within provenances were not assessed.

All flowering trees in each provenance were scored using a data collection tool which indicated males, females, and nonflowering families in each flowering phase. All nonflowering families were recorded towards the end of flowering phase for each provenance. The recording was done from August to October until all the provenances had finished flowering. All the flowering, fruiting, and nonflowering families were recorded separately. Assessment followed the method developed by Shivanna and Tandon [32].

2.5. Data Analysis. Data on fruit length and width, fruit weight, stone weight, and number of windows per stone was analyzed using MINITAB 17.0. One-way Analysis of Variance (ANOVA) as blocking was shown to be ineffective after an initial two-way analysis. Descriptive statistics were used to analyze data on the total number of fruits developed under each of the three mating system treatments. The Pivot table from Microsoft excel was used to derive percentages of fruit development per treatment. Significant effects were separated by using Fisher's Least Significant Difference (LSD) post hoc tests to detect differences between means.

\section{Results}

3.1. Mating System. There were significant $(P<0.05)$ differences in percentage of fruit developed between treatments (Figure 3). The highest fruit development (43\%) occurred from flower buds covered with nets (wind pollination). The lowest fruit development (19\%) was from flower buds covered with khaki envelopes (selfing) (Figure 3). No significant $(P>0.05)$ variations occurred between wind pollination treatment and open pollination (control). Fruits failed to develop under selfing treatment for the Tanzanian provenances which included Magamba subspecies caffra and the bulked provenances of subspecies birrea including Mkata (Kilosa), Ubena (Bagamoyo), and Chalinze (Bagamoyo).

3.2. Fruit Size and Shape. Analysis of Variance showed no significant $(P>0.05)$ statistical differences among treatments in all fruit parameters measured apart from the number of nuts (operculum) (Table 2). Fruits from the different treatments were all comparable in size and shape. 
TABLE 2: Fruit parameters from control and self- and wind-pollinated treatments ( \pm standard error).

\begin{tabular}{lccccc}
\hline Treatments & Width $(\mathrm{cm})$ & Length $(\mathrm{cm})$ & Fruit weight $(\mathrm{g})$ & Seed weight $(\mathrm{g})$ & Number of operculums \\
\hline Free natural pollination (control) & $3.2 \pm 0.06^{\mathrm{a}}$ & $3.8 \pm 0.06^{\mathrm{a}}$ & $20.3 \pm 0.83^{\mathrm{a}}$ & $4.5 \pm 0.26^{\mathrm{a}}$ & $2.2 \pm 0.12^{\mathrm{ab}}$ \\
Self-pollination & $3.2 \pm 0.09^{\mathrm{a}}$ & $3.6 \pm 0.06^{\mathrm{a}}$ & $18.7 \pm 1.54^{\mathrm{a}}$ & $4.2 \pm 0.47^{\mathrm{a}}$ & $2.5 \pm 0.17^{\mathrm{a}}$ \\
Controlled natural pollination (wind) & $3.2 \pm 0.05^{\mathrm{a}}$ & $3.8 \pm 0.07^{\mathrm{a}}$ & $18.6 \pm 0.88^{\mathrm{a}}$ & $4.0 \pm 0.30^{\mathrm{a}}$ & $2.1 \pm 0.11^{\mathrm{b}}$ \\
\hline
\end{tabular}

Means in column followed by the same letter do not differ significantly $(P>0.05)$

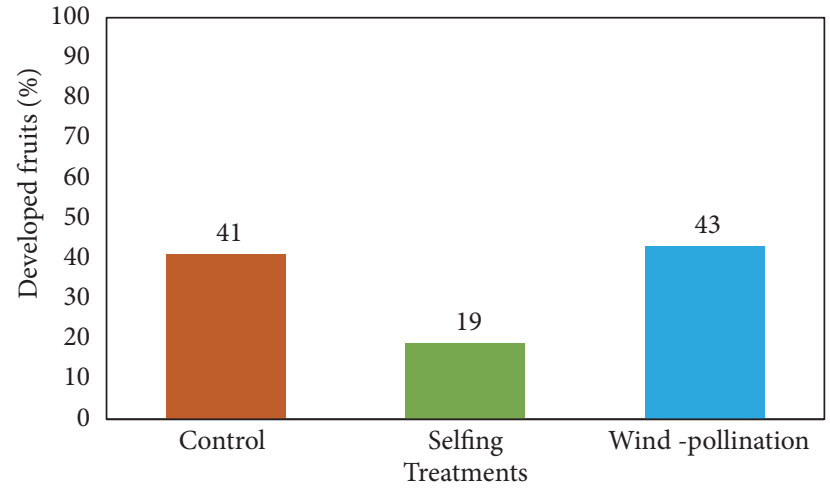

Figure 3: Proportion of fruits developed from selfing, controlled wind pollination, and natural pollination (control) in Marula.

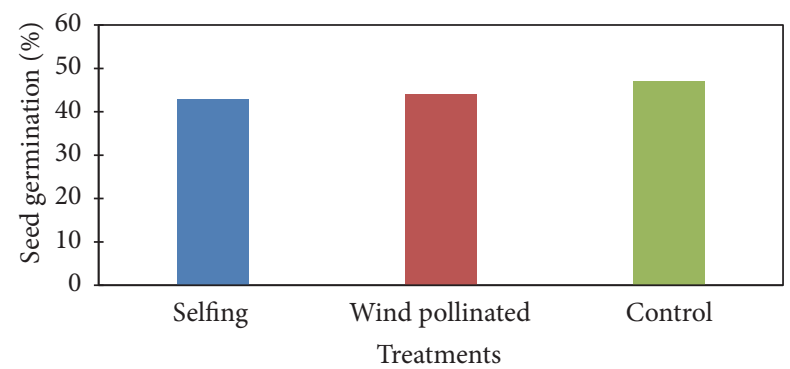

FIGURE 4: Seed germination percentage for the three treatments.

3.3. Seed Germination. Seed from all the three treatments germinated implying that the seed were viable (Figure 4). The germination percentages for control, selfed, and putative wind pollination were $47 \%, 43 \%$, and $44 \%$, respectively, but were not significantly different from each other.

3.4. Flower Visitors. Insects were frequently seen on male than female flowers during the day from 7:30 hr to 16:30 hr local time. A wide diversity of potential pollinators were observed and collected (Table 3 ). The most frequent flower visitors on both the male and female inflorescences included the Hymenoptera of the families Apidae, Vespidae, and Braconidae species Xylocopa incostans, Eumenes spp., and Atanycolus spp., respectively, followed by Lepidoptera of the families Pieridae and Nymphalidae species Afrodryas leda and Acraea acara. A range of insects including Acraea acara (Nymphalidae) and Pentala spp. (Libellulidae), Diptera (Mydidae), and Odonata (Libellulidae) inflorescence visitors were less common (Table 3).

3.5. Sex Ratio. Sex ratio ranged from 1:1 to $1: 8$ of female to males which was determined in $53 \%$ of the total number of trees within the provenances trial that were flowering. The remaining $47 \%$ of the trees were not flowering and therefore their sex could not be ascertained. There were significant $(P<0.05)$ variations in flowering sex ratio among the provenances. Five provenances including Marracuene, Magamba, Tanzania bulked, Ngundu, and Matebeleland South did not deviate from equality (Table 4). The other fifteen provenances showed significant male-biased sex ratio. No provenance was significantly female biased. The overall sex ratio deviated from equality with male-biased sex ratio of 2:1 (Table 4).

\section{Discussion}

\subsection{Mating System}

4.1.1. Pollination by Selfing (Hermaphrodite Flowers Only). In all treatments fruit development was successful and the fruits developed to maturity. The development of viable seed in the flowers covered by the envelope confirmed that efficient self-pollination occurs in S. birrea. The source of pollen is likely that some flowers had both male (staminate) and female (pistillate) organs which enabled selfing to take place. The fact that the seed was viable disqualifies the assumption of apomixes in the species.

The development of fruits and viable seed through selfing treatment is an indication of hermaphrodite flowers with functional male and female organs on the same flower [15]. Even though $S$. birrea is generally described as dioecious tree species reports have indicated the existence of isolated cases of monoecy within the species [11,33]. The development of fruits in selfing treatment and in the open pollination (control) confirms the reports of monoecism and dioecism in $S$. birrea. Therefore, fruit development in enclosed flower buds signifies an occurrence of self-pollination (monoecism). The results further suggest that $S$. birrea produces hermaphrodite flowers that are self-compatible hence the development of fruits in a selfing treatment.

Conversely, the Tanzanian provenances including Magamba, a subspecies caffra, and three pooled provenances also of subspecies birrea failed to develop fruits under selfing treatment suggesting that the provenances are dioecious (outcrossing). In a similar study in Kenya [14] found that bagged racemes of $S$. birrea subspecies birrea failed to set fruits except where pollen was manually applied. Possibly there might be some genetic relationship between the Kenya genotypes and the Tanzanian genotypes due to proximate Geographical location. Nevertheless, there was less fruit development in the selfing treatment compared with the control because the selfing treatment was limited to hermaphrodites' flowers only while the control was exposed to multiple pollen donors such as wind, insects, and self-pollination. 
TABLE 3: Insects observed on Sclerocarya birrea flowers.

\begin{tabular}{lcc}
\hline Order & Family & Species \\
\hline Hymenoptera & Apidae & Xylocapa incostans \\
Hymenoptera & Braconidae & Atanycolus spp. \\
Hymenoptera & Vespidae & Eumenes spp. \\
Lepidoptera & Nymphalidae & Acraea acara \\
Lepidoptera & Pieridae & Afrodryas leda \\
Odonata & Libellulidae & Pentala spp. \\
Diptera & Mydidae & $*$ \\
\hline
\end{tabular}

$*$ : not identified at species level

TABLE 4: Sex ratio of female to male (F: $M)$ in S. birrea provenances.

\begin{tabular}{|c|c|c|c|c|}
\hline Provenance & Total number of healthy trees & Number of Female trees & Number of Male trees & $\begin{array}{c}\text { Ratio } \\
\text { (Female to Male) }\end{array}$ \\
\hline Marracuene & 62 & 34 & 28 & $1: 1$ \\
\hline Magunde & 52 & 16 & 31 & $1: 2$ \\
\hline Moamba & 41 & 9 & 24 & $1: 3$ \\
\hline Kalanga & 23 & 4 & 10 & $1: 3$ \\
\hline Magamba & 47 & 14 & 12 & $1: 1$ \\
\hline Tanzania bulked ${ }^{*}$ & 33 & 10 & 13 & $1: 1$ \\
\hline Missira & 37 & 11 & 19 & $1: 2$ \\
\hline Chikwawa & 36 & 3 & 8 & $1: 3$ \\
\hline Mangochi & 40 & 3 & 5 & $1: 2$ \\
\hline Ntcheu & 42 & 1 & 8 & 1: 8 \\
\hline Rumphi & 29 & 0 & 0 & - \\
\hline Oshikondilingo & 18 & 1 & 5 & 1: 5 \\
\hline Ohangwena & 27 & 2 & 7 & 1: 4 \\
\hline Kalimbeza & 37 & 7 & 16 & 1: 2 \\
\hline Ngundu & 29 & 12 & 13 & $1: 1$ \\
\hline Mudzi & 26 & 2 & 4 & $1: 2$ \\
\hline Biriwiri & 15 & 3 & 9 & 1: 3 \\
\hline Muzarabani & 36 & 1 & 3 & 1: 3 \\
\hline Matebeleland N & 18 & 1 & 5 & 1: 5 \\
\hline Matebeleland S & 19 & 7 & 5 & $1: 1$ \\
\hline Siavonga & 33 & 2 & 15 & 1: 8 \\
\hline Choma & 34 & 0 & 7 & - \\
\hline Mean & 734 & 143 & 247 & $1: 2$ \\
\hline
\end{tabular}

Note: all the provenances had the same species (S. birrea ssp. caffra);

${ }^{*}$ Bulked provenances were as follows: Mkata (Kilosa), Ubena (Bagamoyo), and Chalinze (Bagamoyo)

4.1.2. Fine Netting: Controlled Natural Pollination (Wind and Selfing). Cross-pollination, also known as allogamy, involves the transfer of pollen from an anther on one plant to a stigma of a flower on another plant by using an external agent such as wind, water, and animals [28]. In the present study, there was fruit development in buds that were covered by fine nets. Fruit development in this treatment signifies cross-pollination by wind or selfing by hermaphrodite flowers [34]. The results therefore suggest that the enclosed flower bud got fertilized by pollen blown by wind from male flowers of other trees within the trial. However, in case of hermaphrodite flowers, the possibility of selfing is inevitable in this treatment.
Therefore, we inferred that both wind pollination and selfing occurred under this treatment. The results in this treatment are similar to the control which was exposed to pollination by wind, insects, and selfing demonstrating that contribution to pollination by insect within the control treatment was nonsignificant. Successful fruit development in mosquito net covered buds is similar to the findings of Munthali et al. [35] in a study of Adansonia digitata where effective fruit development occurred in mosquito net covered treatments and attributed it to wind pollination. Although morphological evidence and observations have suggested insects as major pollinators in S. birrea [11], current results seem to 
suggest wind as the major pollination agent. The study does not however eliminate the potential contribution of insects. Results of this study confirmed our alternate hypothesis that $S$. birrea has mixed mating systems which include selfing and cross-pollination.

\subsection{Inflorescence Development}

4.2.1. Bud and Fruit Development. Low fruit development was recorded in all the three treatments with the control inclusive. Flower buds covered with envelope (19\%), mosquito nets (43\%), and open pollination (41\%) signify high abortion rate both at bud and at fruitlet stages in all the treatments (Figure 4). The envelope treatment registered the highest total abortion rate (81\%) unlike the net treatment that did not significantly vary with the control (Figure 4). High fruit abortion rate in $S$. birrea was noted by Mkwezalamba et al. [27] in natural pollination system. Similarly, high fruit abortion rate has been reported in different species such as Adansonia digitata [35] in selfing treatment and Tectona grandis [36] in cross-pollination treatment but causes are not clearly known and further research is recommended to ascertain the causes.

The high abortion rate in envelope covered buds might have resulted from pollen limitation because the envelope cover eliminated cross-pollination. Nevertheless, fruit abortion in all the treatments including the control could be attributed to resource limitation. However most tropical trees have a tendency of producing excessive flowers either to attract flower visitors or to ensure the availability of pollen and are aborted soon after blooming [18]. According to Sreekala [29] flower and juvenile fruit abscission permit plants to match fruit and seed number with the available resources over a wide range of environmental conditions.

4.2.2. Seed Germination. Seed germination from all the treatments is an indication of effective pollination and viable embryos [35]. The results seem to fill in the gap identified by Diallo et al. [10] and Munjuga [14] who reported female flowers bearing staminodes with viable pollen but never investigated whether these flowers were self-compatible or not. Therefore, the results have indicated that, apart from the well-known dioeciousness, the species is also monoecious and hermaphrodite and produces self-compatible flowers.

4.3. Sclerocarya birrea Flower Visitors. The peak visitation periods (7:00hr to $11: 30 \mathrm{hr}$ and $15: 30$ to $18: 00 \mathrm{hr}$ ) correspond to cooler temperatures in the morning and evening and also to the flower opening period as reported by Hall et al. [11] that fully developed buds of $S$. birrea open between dawn and midday. Most of the flying insects were caught hovering around and scavenging on the anthers possibly picking or feeding on pollen. The most frequent flower visitors in the study were the orders Hymenoptera of the families Apidae, Vespidae, and Braconidae and Lepidoptera of the families Nymphalidae and Pieridae (Table 2). Nevertheless, the honey bees (Apidae: Apis mellifera) are usually cited as a main pollinator of subsp. birrea and caffra $[11,14]$. Apart from honey bees (Apidae and Megachilidae), flies (Muscidae: Musca spp.) and hoverflies (Syrphidae) Wasps (Scoliidae) are reported as secondary pollination agents [14], although the current results did not manage to capture pollen vectors reported in the secondary category. The findings are also supported by Janick and Paul [37] and Goldblatt and Manning [38] who reported that the honey bee Eumenes spp. (Vespidae) is one of the commonest pollinators of S. birrea. Furthermore, morphological evidence and observations suggest that $S$. birrea is an entomophilous species that produces sticky pollen and secretes nectar hence the honeybee being a major pollinator [11].

However, not all flower visitors are pollinators. Others visit just for feeding on pollen and nectar while others are predators and visit flowers either to eat the corolla or to lay eggs $[39,40]$. For example, the order Lepidoptera (moth) was captured among flower visitors but eventually it was discovered that the larvae caused serious leaf damage in S. birrea. This indicates that they were not merely flower visiting. Probably, they were laying eggs as well. Secondly, the current study also noted fruits with perforations that caused severe oozing of sap on the surface and after fruit incubation adult fruit flies emerged from the decomposing fruits. However, detailed studies are required to understand contribution of the other insect species that were found inhabiting in open flowers. A wide diversity of potential pollinators were observed and collected. The most regular flower visitors on both the male and female inflorescences included the Hymenoptera of the families Apidae, Vespidae and Braconidae species Xylocopa incostans, Eumenes spp., and Atanycolus spp. consecutively followed by Lepidoptera of the families Pieridae and Nymphalidae species Afrodryas leda and Acraea acara. Inflorescence visitors from orders Diptera (Mydidae) and Odonata (Libellulidae) were less common (Table 3).

4.4. Sex Ratio. The sex ratio of female to males ranged from $1: 1$ to $1: 8$ with only five provenances maintaining the $1: 1$ ratio while the remaining fifteen deviated from equality. The overall average for the population was one female against two males (1:2). However, in unselected natural stands, a sex ratio of 1:1 has been reported [22]. On the contrary, sexual selection supposition for the evolution of dioecy forecasts a male-biased sex ratio along with more flower production with prolonged period of flowering [22, 31]. However, the departure from equality in the 15 provenances one could argue that perhaps more females are still to come into flower and this may shift the ratio to $1: 1$. We can therefore speculate that perhaps female trees flower late compared to males. It can also be noted in the ratio table that the ratios deviating from unity are associated with overall fewer trees in flower at the time of assessment. Where there were more trees flowering, the tendency is towards unity. Nevertheless, a greater number of studies in dioecious plants have attributed sex biasness to sex-differentiated mortality to stressful habitats [22] with female's plants investing more in reproductive activities and less in growth and maintenance compared to male [15].

The present results on the dioecious behavior of $S$. birrea are similar to the findings of Jenya et al. [41] in a study of Uapaca kirkiana provenances trial in Malawi where six 
out of seven genotypes significantly deviated from equality with a male-biased sex ratio. It is also comparable to the findings of Gao et al. [42] in a study of eight dioecious species where they found a male-biased sex ratio in four and one female-biased sex ratio while the other three had more males flowering but with no significant differences. In addition, comparative surveys of dioecious flowering plants have commonly revealed biased sex ratios, almost twice as common in male-biases than female-biases [21, 41]. The male-biased sex ratio is a demerit to tree domestication programs because the main idea is to achieve high fruit yield both for social and for economic purposes; hence having more males than females potentially signifies less fruit yield. Nevertheless, females found within male-biased populations will have an increased access to pollen donors to effect fertilization and enhance the production of surplus embryos, which would enable selective abortion of lower quality seeds [18]. Furthermore, reproductive benefits attributed to females occurring within male-biased populations may be essential to repay for the greater reproductive costs experienced by females that attract seed dispersers with production of heavy fruits [21].

A 1:1 sex ratio is possible in undisturbed populations of S. birrea and other dioecious species [43], although it is difficult to achieve when plants are raised from seed where it is not possible to differentiate the sex. Thus for commercial operation the results seem to suggest the use of vegetative propagation as a means of mass production where both males and female trees should be regenerated. At present the required ratio for the fruit orchard is not known. However, commercial production should have higher number of females than males provided they are adequate males to fully pollinate all the females [44]. This is an area that requires further study.

Furthermore, to complement this study of mating system, future studies should use gene markers analysis, such as microsatellite loci, which can reveal selfing rate, mating among related trees, correlated mating, inbreeding, genetic diversity, and differentiation among the populations.

\section{Conclusion}

The study has revealed that the mating system in S. birrea occurred from selfing, insect, and wind-mediated pollination. These results confirm that the species of $S$. birrea subspecies caffra and birrea has a multiple mating system and that it is both dioecious and monoecious with insects and wind as pollination agents. The species also produces hermaphrodite flowers as confirmed by the viable seed from selfing. Production of viable seed from selfed flowers ruled out the possibility of apomixes in the species. Most frequent flower visitors during the study were the orders Hymenoptera and Lepidoptera with peak visitation period being 7:00 hr to $11: 30 \mathrm{hr}$ in the morning and then $15: 30 \mathrm{hr}$ to $18: 00 \mathrm{hr}$ (local time) in the afternoon when temperatures were cooler. The periods corresponded to the flower opening periods. The species displayed sex ratio of female to male ranging from 1:1 to 1:8 with only five (Marracuene, Magamba, Tanzania pooled, Ngundu, and Matebeleland South) provenances maintaining the 1:1 ratio while the remaining fifteen deviated from equality. The overall average for the population was one female against two males (1:2).

\section{Data Availability}

The data that support the findings of this study can be obtained from the corresponding author upon request.

\section{Conflicts of Interest}

The authors declare that they have no conflicts of interest.

\section{Acknowledgments}

The authors are grateful to the Forestry Research Institute of Malawi (FRIM) staff for assisting in field data collection. This research was funded by World Agroforestry Centre through their internship program.

\section{References}

[1] A. I. de-Lucas, J. J. Robledo-Arnuncio, E. Hidalgo, and S. C. González-Martínez, "Mating system and pollen gene flow in Mediterranean maritime pine," Heredity, vol. 100, no. 4, pp. 390 399, 2008.

[2] S. Glémin, E. Bazin, and D. Charlesworth, "Impact of mating systems on patterns of sequence polymorphism in flowering plants," Proceedings of the Royal Society B Biological Science, vol. 273, no. 1604, pp. 3011-3019, 2006.

[3] S. Kikuchi, M. Shibata, and H. Tanaka, "Effects of forest fragmentation on the mating system of a cool-temperate heterodichogamous tree Acer mono," Global Ecology and Conservation, vol. 3, pp. 789-801, 2015.

[4] M. A. Moraes, A. P. S. Gaino, M. L. T. Moraes, M. L. M. Freitas, and A. M. Sebbenn, "Estimating coancestry within open-pollinated progenies of a dioecious species: the case study of Myracrodruon urundeuva," Silvae Genetica, vol. 61, no. 6, pp. 256-264, 2012.

[5] B. O. Muok, S. G. Khumalo, W. Tadesse, and S. H. Alem, "Sclerocarya birrea, marula," in Proceedings of the Conservation and Sustainable Use of Genetic Resources of Priority Food Tree Species in sub-Saharan Africa, Biodiversity International, Rome, Italy, 2011.

[6] M. T. Masarirambi and K. A. Nxumalo, "Post-harvest physiological indicators on the phenotypic variation of marula fruits (Sclerocarya birrea subspp. caffra) in Swaziland," International Journal of Biology, Pharmacy and Allied Sciences, vol. 1, no. 8, pp. 1025-1039, 2012.

[7] S. A. Mng'omba, G. W. Sileshi, R. Jamnadass, F. K. Akinnifesi, and J. Mhango, "Scion and Stock diameter size effect on growth and fruit production of Sclerocarya birrea (Marula) trees," Journal of Horticulture and Forestry, vol. 4, no. 9, pp. 153-160, 2012.

[8] S. E. Shackleton, C. M. Shackleton, T. Cunningham, C. Lombard, C. A. Sullivan, and T. R. Netshiluvhi, "Knowledge on Sclerocarya birrea subsp. caffra with emphasis on its importance as a non-timber forest product in South and southern Africa: a summary. Part 1: taxonomy, ecology and role in rural livelihoods," Southern African Forestry Journal, vol. 194, pp. 27-41, 2002. 
[9] P. B. Kando, C. Bisseye, R. K. Nanema et al., "Genetic diversity of Sclerocarya birrea subspecies birrea populations in Burkina Faso detected by RAPDs," African Journal of Biotechnology, vol. 11, no. 1, pp. 99-108, 2016.

[10] B. O. Diallo, D. Mckey, M.-H. Chevallier, I. Hélène, H. I. Joly, and M. Hossaert-Mckey, "Breeding system and pollination biology of the semidomesticated fruit tree, Tamarindus indica L. (Leguminosae: Caesalpinioideae): implications for fruit production, selective breeding, and conservation of genetic resources," African Journal of Biotechnology, vol. 7, no. 22, pp. 4068-4075, 2008.

[11] J. B. Hall, E. M. O'Brien, and F. L. Sinclair, Sclerocarya birrea: A Monograph, Publication Number 19, School of Agricultural and Forest Sciences, University of Wales, Bangor, UK, 2002.

[12] I. Teichman, "Notes on the distribution, morphology, importance and uses of the indigenous Anacardiaceae. The distribution and morphology of Sclerocarya birrea (the marula)," Trees in South Africa, vol. 34, no. 3, pp. 35-41, 1982.

[13] C. B. Todd, "A survey of fruit production in Sclerocarya birrea (marula)," in Project number 354E3.4. Final Report, p. 9, Venda University, Thohoyandou, South Africa, 2001.

[14] M. R. Munjuga, "Sclerocarya birrea subspecies birrea (A. Rich.) Hochst," in Sclerocarya birrea: A Monograph School of Agricultural and Forest Sciences, J. B. Hall, E. M. OBrien, and F. L. Sinclair, Eds., University of Wales, Bangor, UK, 2000.

[15] G. N. Gouwakinnou, A. M. Lykke, B. A. Djossa, and B. Sinsin, "Folk perception of sexual dimorphism, sex ratio, and spatial repartition: implications for population dynamics of Sclerocarya birrea [(A. Rich) Hochst] populations in Benin, West Africa," Agroforestry Systems, vol. 82, no. 1, pp. 25-35, 2011.

[16] E. Nghitoolwa, J. B. Hall, and F. L. Sinclair, "Population status and gender imbalance of the marula tree, sclerocarya birrea subsp. caffra in northern Namibia," Agroforestry Systems, vol. 59, no. 3, pp. 289-294, 2003.

[17] T. M. Knight, J. A. Steets, J. C. Vamosi et al., "Pollen limitation of plant reproduction: pattern and process," Annual Review of Ecology, Evolution and Systematics, vol. 36, no. 1, pp. 467-497, 2005.

[18] K. M. Johnson and S. E. Nielsen, "Demographic effects on fruit set in the dioecious shrub Canada buffaloberry (Shepherdia canadensis)," Peer Journal, vol. 2, no. e526, 2014.

[19] L. F. Delph, "Sexual dimorphism in life history," in Gender and Sexual Dimorphism in Flowering Plants, M. A. Geber, T. E. Dawson, and L. F. Delph, Eds., pp. 149-174, Springer, Berlin, Germany, 1999.

[20] S. C. H. Barrett, S. B. Yakimowski, D. L. Field, and M. Pickup, "Ecological genetics of sex ratios in plant populations," Philosophical Transactions of the Royal Society B: Biological Sciences, vol. 365, no. 1552, pp. 2549-2557, 2010.

[21] D. L. Field, M. Pickup, and S. C. H. Barrett, "Comparative analyses of sex-ratio variation in dioecious flowering plants," Evolution, vol. 67, no. 3, pp. 661-672, 2012.

[22] L. Yu and J. Lu, "Does landscape fragmentation influence sex ratio of dioecious plants? a case study of pistacia chinensis in the thousand-island lake region of China," PLoS ONE, vol. 6, no. 8, article e22903, 2011.

[23] R. J. Bwanali, G. Chikalema, W. Sagona, and P. W. Chirwa, "Phenological studies of an international provenance trial of Sclerocarya birrea in Malawi," in Proceedings of the Forest Research Institute Report 04003, Institute of Malawi, 2004.

[24] V. Msukwa, C. R. Y. Munthali, E. Missanjo et al., "Growth performance and fruit production of sclerocarya birrea(a. rich.)
Hochst. Provenances in Malawi," International Journal of Scientific Research in Agricultural Sciences, vol. 3, no. 2, pp. 042-049, 2016.

[25] B. I. Nyoka, T. Chanyenga, S. A. Mngomba, F. K. Akinnifesi, and W. Sagona, "Variation in growth and fruit yield of populations of Sclerocarya birrea (A. Rich.) Hochst.", Agroforestry Systems, vol. 89, no. 3, pp. 397-407, 2015.

[26] P. W. Chirwa, R. J. Bwanali, G. Meke, W. Sagona, C. R. Y. Munthali, and L. Mwabumba, "Growth and phenology of a three- to four-year-old Sclerocarya birrea international provenance trial in Malawi," Southern Hemisphere Forestry Journal, vol. 69, no. 1, pp. 49-54, 2007.

[27] I. Mkwezalamba, C. R. Y. Munthali, and E. Missanjo, "henotypic Variation in Fruit Morphology among Provenances of Sclerocarya birrea (A. Rich.) Hochst," International Journal of Forestry Research, vol. 2015, Article ID 735418, 8 pages, 2015.

[28] C. V. Helm, S. L. Scott, and E. T. F. Witkowski, "Reproductive potential and seed fate of Sclerocarya birrea subsp. caffra (marula) in the low altitude savannas of South Africa," South African Journal of Botany, vol. 77, no. 3, pp. 650-664, 2011.

[29] A. K. Sreekala, "Importance of plant reproductive biology in conservation," in Proceedings of the National Conference on "Bioresources: Conservation, Utilization and Future Prospects, 2017, https://www.researchgate.net/publication/314364124.

[30] A. V. Etcheverry, M. M. Alemán, and T. F. Fleming, "Flower Morphology, Pollination Biology and Mating System of the Complex Flower of Vigna Caracalla (Fabaceae: Papilionoideae)," Annals of Botany, vol. 102, no. 3, pp. 305-316, 2008.

[31] M. R. Ngulube, J. B. Hall, and J. A. Maghembe, "Fruit, seed and seedling variation in Uapaca kirkiana from natural populations in Malawi," Forest Ecology and Management, vol. 98, no. 3, pp. 209-219, 1997.

[32] K. R. Shivanna and R. Tandon, Reproductive Ecology of Flowering Plants. A Manual, Springer, New Delhi, India, 2014.

[33] B. O. Muok, S. G. Khumalo, W. Tadesse, and S. Alem, Sclerocarya birrea, Marula. Conservation and Sustainable Use of Genetic Resources of Priority Food Tree Species in sub-Saharan Africa, Biodiversity International, Rome, Italy, 2011.

[34] E. Lahiani, P. Touzet, E. Billard, and M. Dufay, "When is it worth being a self-compatible hermaphrodite? Context-dependent effects of self-pollination on female advantage in gynodioecious Silene nutans," Ecology and Evolution, vol. 5, no. 9, pp. 1854-1862, 2015.

[35] C. R. Y. Munthali, P. W. Chirwa, and F. K. Akinnifesi, "Phenotypic Variation in fruit and seed morphology of Adansonia digitata L. (baobab) in five selected wild populations in Malawi," Agroforestry Systems, vol. 85, no. 2, pp. 279-290, 2012.

[36] E. R. Palupi, J. N. Owens, S. Sadjad, . Sudarsono, and D. D. Solihin, "The importance of fruit set, fruit abortion, and pollination success in fruit production of teak (Tectona grandis)," Canadian Journal of Forest Research, vol. 40, no. 11, pp. 2204-2214, 2010.

[37] J. Janick and E. Paul, The Encyclopedia of Fruits and Nuts, 2006.

[38] P. Goldblatt and J. C. Manning, "Radiation of pollination systems in the Iridaceae of sub-Saharan Africa," Annals of Botany, vol. 97, no. 3, pp. 317-344, 2006.

[39] J. Genini, L. P. Morellato, P. R. Guimarães, and J. M. Olesen, "Cheaters in mutualism networks," Biology Letters, vol. 6, no. 4, pp. 494-497, 2010.

[40] N. P. Dias, D. E. Nava, M. S. Garcia, F. F. Silva, and R. A. Valgas, "Oviposition of fruit flies (Diptera: Tephritidae) and its relation with the pericarp of citrus fruits," Brazilian Journal of Biology, vol. 78, no. 3, pp. 443-448, 2018. 
[41] H. Jenya, C. Munthali, E. Missanjo, M. Chirwa, and W. Sagona, "Variations in phenology and morphology of Uapaca kirkiana Mull Arg. Provenances at Nauko in Liwonde Forest Reserve, Malawi," Journal of Scientific Research and Reports, vol. 10, no. 3, pp. 1-13, 2016.

[42] J. Gao, S. A. Queenborough, and J. P. Chai, "Flowering sex ratios and spatial distribution of dioecious trees in a South-East Asian seasonal tropical forest," Journal of Tropical Forest Science, vol. 24, no. 4, pp. 517-527, 2012.

[43] D. M. A. Daldoum, M. M. Massaud, and Y. O. Adam, "Distribution, fruit production and natural regeneration of Sclerocarya birrea (A. Rich.) Hochst. Subsp. birrea in the Nubba Mountains, Sudan," Agricultural Research and Reviews, vol. 1, no. 5, pp. 148152, 2012.

[44] J. P. Sinclair, Dioecious Plants: Evolution and Sex Ratio and Aspen Decline, Wayne State University Dissertations, 2012. 

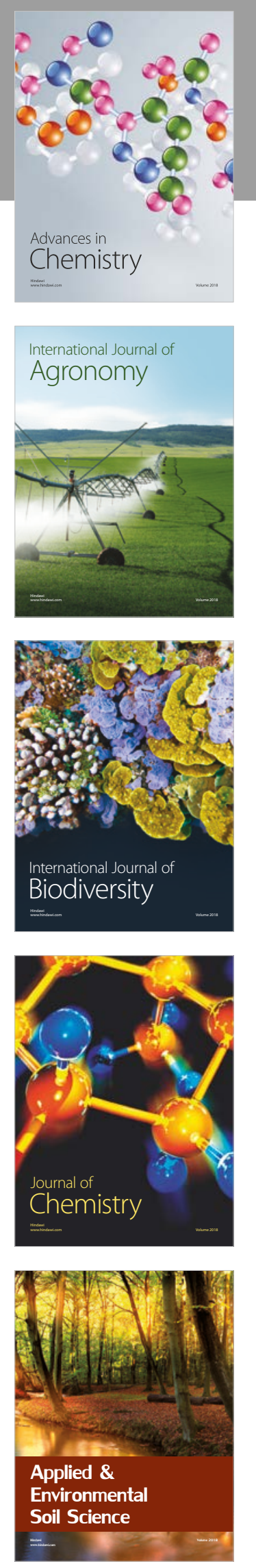

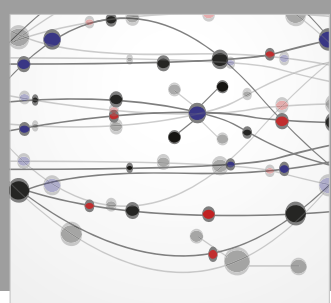

The Scientific World Journal

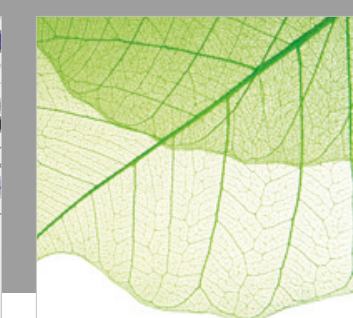

Journal of Botany

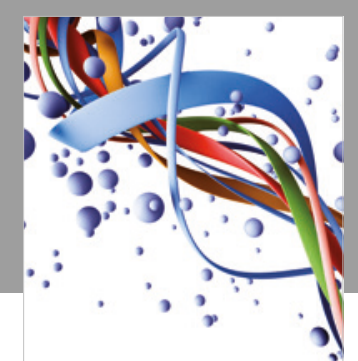

Scientifica

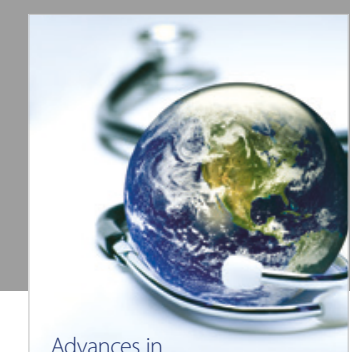

Public Health

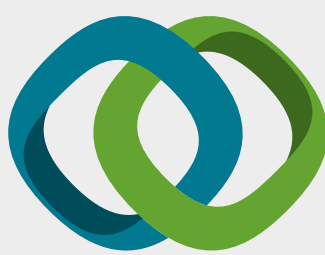

Hindawi

Submit your manuscripts at

www.hindawi.com
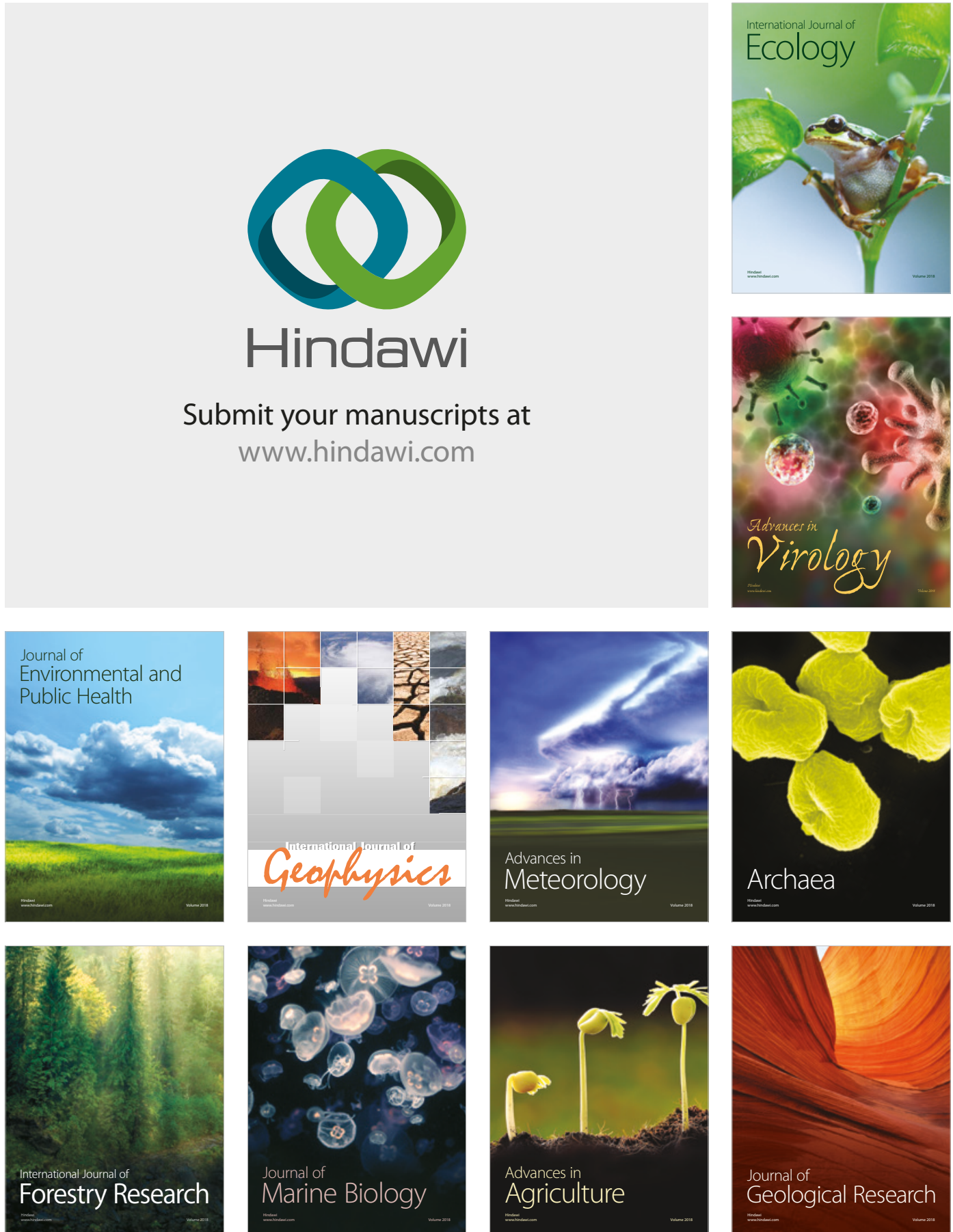

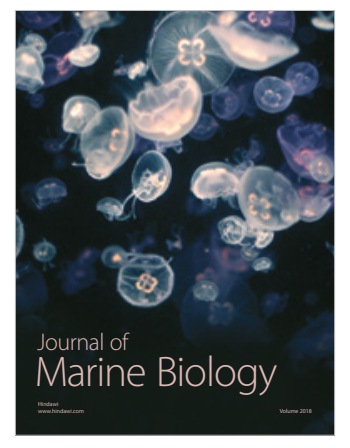

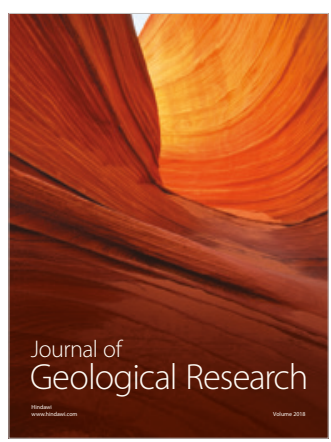

